\title{
RNA FROM FRESH FROZEN CRYOSECTIONS OF OIL PALM INFLORESCENCES IS SUPERIOR TO FFPE SECTIONS
}

\author{
SOOK-KEAT CHAI ${ }^{*, * *}$; PARAMESWARI NAMASIVAYAM**; CHAI-LING HO**; ABDUL AZIZ NORAZLIN; \\ MEILINA ONG-ABDULLAH* and SIEW-ENG OOI*
}

\begin{abstract}
Formalin-fixed, paraffin-embedded (FFPE) and fresh frozen (FF) tissue sections are valuable sources for histology and molecular studies. However, FFPE tissue sections usually provide poor quality RNA that is unsuitable for most downstream molecular applications. In this study, tissue preparation for cryosectioning and RNA extraction protocols were optimised for FF oil palm inflorescences. FF tissue treated with sucrose offered good cellular image resolution and more importantly, good RNA quality. Higher RNA quality with good RIN values (>6) was obtained from FF sections compared to the fragmented RNA from FFPE tissue sections. However, FFPE sections provided better resolution in terms of cellular morphology. The quality of cellular morphology of the FF sections was moderate, but was sufficient to distinguish the different cell types. Hence, FF oil palm inflorescences is a better choice for downstream transcriptomics studies that require tissue sections without compromising the cytological details.
\end{abstract}

Keywords: fresh frozen tissue sections, sucrose, microscopy, cytological studies, FFPE.

Date received: 12 November 2015; Sent for revision: 16 November 2015; Received in final form: 29 February 2016; Accepted: 1 March 2016.

\section{INTRODUCTION}

In the oil palm, the mantling abnormality affects flower and fruit development, thus jeopardising oil yield from mantled palms (Ong-Abdullah et al., 2015). Large scale genomic studies using transcriptomic sequencing offer a comprehensive view of the molecular events underlying plant development. A combination of cytological characterisation and next generation sequencing technologies would provide comprehensive histological and molecular information on the abnormality. Hence, the challenge in the preparation

Malaysian Palm Oil Board, 6 Persiaran Institusi, Bandar Baru Bangi, 43000 Kajang, Selangor, Malaysia.

E-mail: oseng@mpob.gov.my

** Department of Cell and Molecular Biology, Faculty of Biotechnology and Biomolecular Sciences, Universiti Putra Malaysia, 43400 UPM Serdang, Selangor, Malaysia.

‡ Molecular Pathology Unit, Cancer Research Centre (CaRC), Institute for Medical Research, Jalan Pahang, 50588 Kuala Lumpur, Malaysia. of samples for simultaneous morphological and molecular characterisation is to find a balance between preservation of tissue morphology and also maintaining an intact quality of bio-analytes such as RNA, DNA and protein for further downstream studies. Histological or cytological characterisation methods which are widely used to examine various types of samples allow morphological examination of detailed tissue or cell structures. The method chosen for the preparation of histological samples differ according to the type of samples and further requirements for the examination of the sample (Ganjali, 2012). In histopathology laboratories, among the most common methods used to prepare tissues for examination are the preparation of thin sections from formalin-fixed, paraffin embedded (FFPE) tissues and cryosections from fixed or fresh frozen $(\mathrm{FF})$ specimens.

In general, FFPE tissues are prepared from fresh tissues that are fixed in formalin, a crosslinking fixative that is commonly used to preserve cytoskeletal and protein structural integrity. The tissues are then embedded in paraffin wax. It is 
known that the recovery of intact RNA from FFPE samples is one of the main challenges faced by scientists (Evers et al., 2011). The formalin-based fixation procedure introduces hydroxymethylene cross-linking bridges between proteins and nucleic acids, proteins and macromolecules or between proteins, which impede the extraction of pure RNA (Vassilakopoulou et al., 2015). Cross-linking can be detrimental to nucleic acids and compromises the RNA for use in PCR, reverse transcription, etc., due to inaccessibility of the RNA by RNA polymerase. Cross-linking however, enables preservation of tissue and cellular structures in their original state, unlike alcohol-based denaturing fixatives which can cause tissues to undergo shrinkage and dryness. Due to these advantages, formaldehyde remains a versatile cross-linking fixative in histology experiments (Scicchitano et al., 2006).

Cryopreservation of freshly sampled tissue in optimal cutting temperature (OCT) embedding medium and snap freezing in liquid nitrogen allows extraction of intact RNA for downstream molecular analyses. Besides that, rapid fixation can be done prior to cryopreservation. It also allows for long-term storage without impairment of the RNA quality. Hence, this is a more reliable archival storage method. However, frozen tissues are sometimes not easily available in tissue archives and require more space. Moreover, collection and preservation of tissues at $-80^{\circ} \mathrm{C}$ or in liquid nitrogen in the longterm are more costly. The morphology of FF tissues may also be compromised due to improper freezing procedures.

In comparison to FF tissues, FFPE tissues can be stored at room temperature or at $4^{\circ} \mathrm{C}$ for long periods with minimal logistic costs (Walter et al., 2013). The cell structure and morphology of FFPE tissues are also well preserved. This is particularly crucial for plant cells, which contain large central vacuoles that can easily collapse during processing (Teixeira and Pereira, 2011). Nonetheless, RNA from FFPE tissues is of poor quality due to its extensive degradation caused by formalin fixation (Ravo et al., 2008) and paraffin-embedding procedures (Evers et al., 2011).

To the best of our knowledge, a method for the isolation of RNA from FF oil palm tissue cryosections has not been described previously. In this study, FF and cryosection protocols were optimised for oil palm inflorescences. Cellular morphology and integrity of the RNA extracted from the FF tissue sections were evaluated in comparison with RNA from FFPE tissue sections.

\section{MATERIALS AND METHODS}

\section{Reagents}

All reagents used in this protocol were purchased from Merck KGaA, Germany or SigmaAldrich, USA, unless otherwise stated.

\section{FFPE-tissue Fixation}

The FFPE protocol for processing of oil palm inflorescences was carried out according to Ramachandran et al. (2014) with minor modifications, i.e. tissue sections were stained with $1 \%(\mathrm{w} / \mathrm{v})$ toluidine blue instead of $1 \%(\mathrm{w} / \mathrm{v})$ napthol blue black.

\section{Preparation of Fresh Frozen Inflorescences for Cryosectioning}

The overall optimisation workflow for this section is as depicted in Figure 1. Fresh

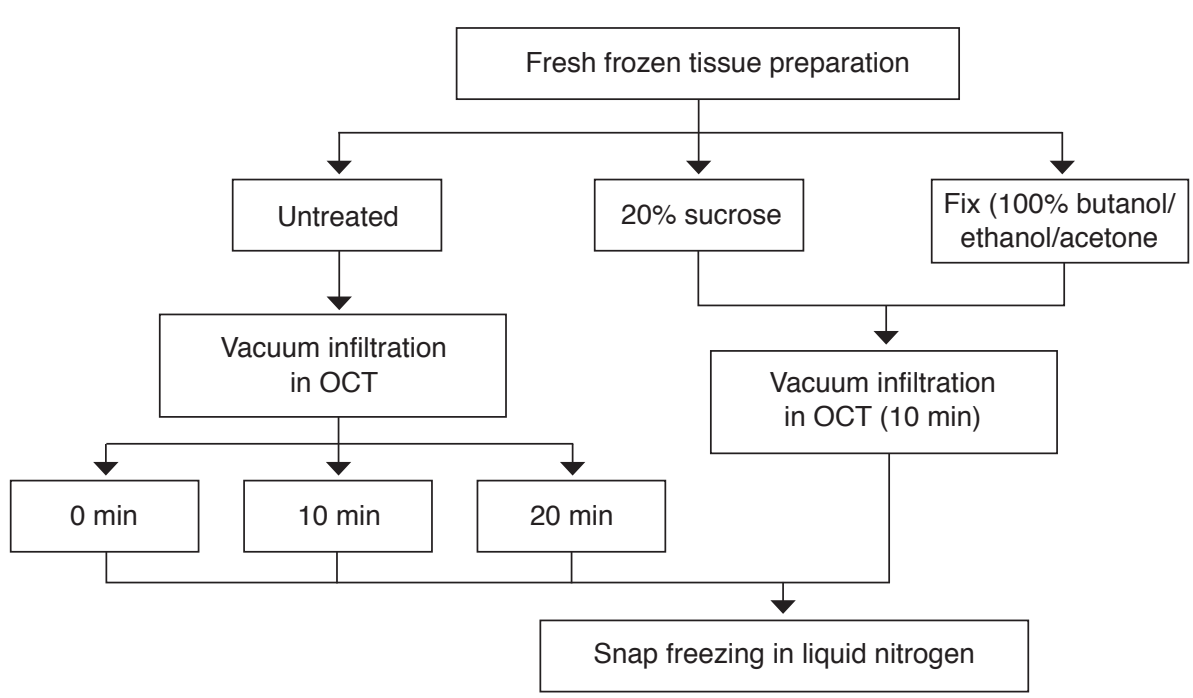

Note: OCT - optimal cutting temperature.

Figure 1. Flow chart for optimisation of fresh frozen tissue processing protocol for oil palm inflorescences 
inflorescences were directly embedded in optimal cutting temperature $\left(O C T\right.$, Tissue-Tek ${ }^{\circledR}$, Sakura ${ }^{\circledR}$ Finetek, USA) embedding compound in plastic molds (Thermo Fisher Scientific, USA) or briefly treated with pre-chilled 20\% (w/v) sucrose or fixed in $100 \%(\mathrm{v} / \mathrm{v})$ butanol, $100 \%(\mathrm{v} / \mathrm{v})$ ethanol or $100 \%$ $(\mathrm{v} / \mathrm{v})$ acetone for $4 \mathrm{hr}$ prior to vacuum infiltration in OCT embedding medium at $20 \mathrm{mPa}$. Duration of the vacuum was tested on untreated fresh inflorescences at 0,10 and $20 \mathrm{~min}$. Tissues that were sucrose-treated or fixed in OCT embedding medium were placed in a vacuum chamber at $20 \mathrm{mPa}$ for $10 \mathrm{~min}$ prior to snap freezing in liquid nitrogen. The frozen tissue molds were stored at $-80^{\circ} \mathrm{C}$ until cryosectioning.

The samples were sectioned using a cryostat (Leica Biosystems, Germany) at $-23^{\circ} \mathrm{C}$. Ten sections at $10 \mu \mathrm{m}$ thickness were obtained for each test. The sections were processed through an ethanol series [95\%, 75\% (v/v) ethanol for $30 \mathrm{~s}$ each] followed by staining with $1 \%(\mathrm{w} / \mathrm{v})$ toluidine blue or left unstained, and washing with $0.1 \%$ (v/v) DEPCtreated water. The sections were then dehydrated in an ethanol gradient series for $30 \mathrm{~s}$ each $[75 \%, 95 \%$, $100 \%, 100 \%$ (v/v) ethanol] prior to RNA extraction or imaging.

\section{RNA Isolation}

RNA extraction was carried out with the RNeasy Mini kit (Qiagen, Germany) according to the manufacturer's instructions. To assess RNA quality, $1 \mu 1$ of RNA was electrophoresed on a $2 \%(\mathrm{w} / \mathrm{v}) 1 \mathrm{X}$ TAE agarose gel, stained with $1 \mu \mathrm{g} \mathrm{ml}^{-1}$ ethidium bromide. Alternatively, RNA was analysed on the 2100 BioAnalyser with RNA 6000 Nano Labchip kit (Agilent Technologies, Germany).

\section{RESULTS AND DISCUSSION}

\section{FFPE Tissue Sections Provided Good Morphological Resolution but Degraded RNA}

RNA obtained from FFPE tissue sections was degraded as a RNA smear was observed from gel electrophoresis (Figure 2a). This RNA was thus unsuitable for molecular experiments. Several factors may have contributed to the RNA fragmentation. The addition of monomethyl groups to the bases in the fixative modifies the nucleic acids, causing them to become more rigid and susceptible to shearing. Besides that, xylene deparaffinisation would have impaired RNA quality (Scicchitano et al., 2006). Paraffin embedding also produces high molecular weight RNA aggregates leading to poor and low RNA yields (Evers et al., 2011).

However, clear and good cellular morphology visualisation of toluidine blue-stained FFPE tissue sections was obtained (Figure 2b). Floral meristems

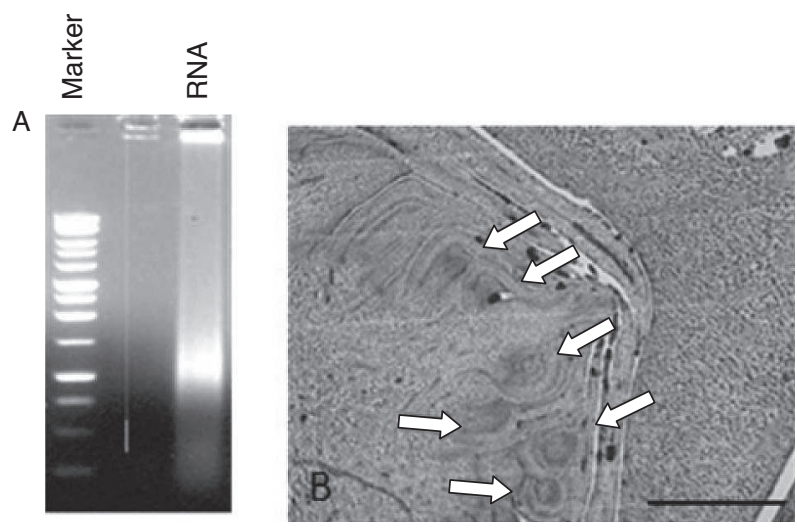

Figure 2. RNA and stained tissue sections from formalin-fixed, paraffinembedded (FFPE)-tissues. Gel electrophoresis of RNA extracted from tissue sections stained with $1 \%(w / v)$ toluidine blue (A). Cellular morphology of toluidine blue-stained tissue sections (B). Arrows indicate floral meristems. Scale bar $=200 \mu \mathrm{m}$.

containing large nuclei were observed as the cells underwent chromatin condensation (Adam et al., 2005). Cellular organelles were well preserved in formaldehyde-fixed tissues and any irregularities could be identified clearly. Hence, good image visualisation of cellular compartments was obtained with FFPE sections. Furthermore, formaldehydefixed tissues were found to be stable for long-term storage with no microorganism growth observed (Grizzle, 2009). The FFPE tissue sections thus yielded clear and discrete cell morphology but provided poor RNA integrity. Hence, a different tissue preparation was needed to obtain good cellular visualisation and intact RNA from tissue sections for downstream molecular studies.

\section{FF Tissue Sections Provided Better RNA Integrity and Clear Cellular Morphology}

We evaluated the effects of tissue fixation in the preparation of fixed-frozen specimens and we compared these with the results obtained from fresh frozen specimens. Various fixatives were tested. Alcohol-based fixatives such as butanol, ethanol and acetone have been evaluated in other tissues (Eltoum et al., 2001). Osmotic shrinkage of the oil palm inflorescence tissue was observed when the tissue was fixed in butanol, ethanol and acetone, while moderate shrinkage was observed in the tissues fixed with ethanol (Figure 3). In contrast, better tissue morphology was obtained with non-fixed tissue sections that were vacuuminfiltrated in OCT embedding compound at $20 \mathrm{mPa}$ for $20 \mathrm{~min}$. The floral meristems containing highly condensed chromatin can be visibly recognised from the surrounding vacuolated cells. Besides that, sucrose-treated tissue sections also provided similar morphological resolution compared to the untreated tissue sections which were vacuum infiltrated 

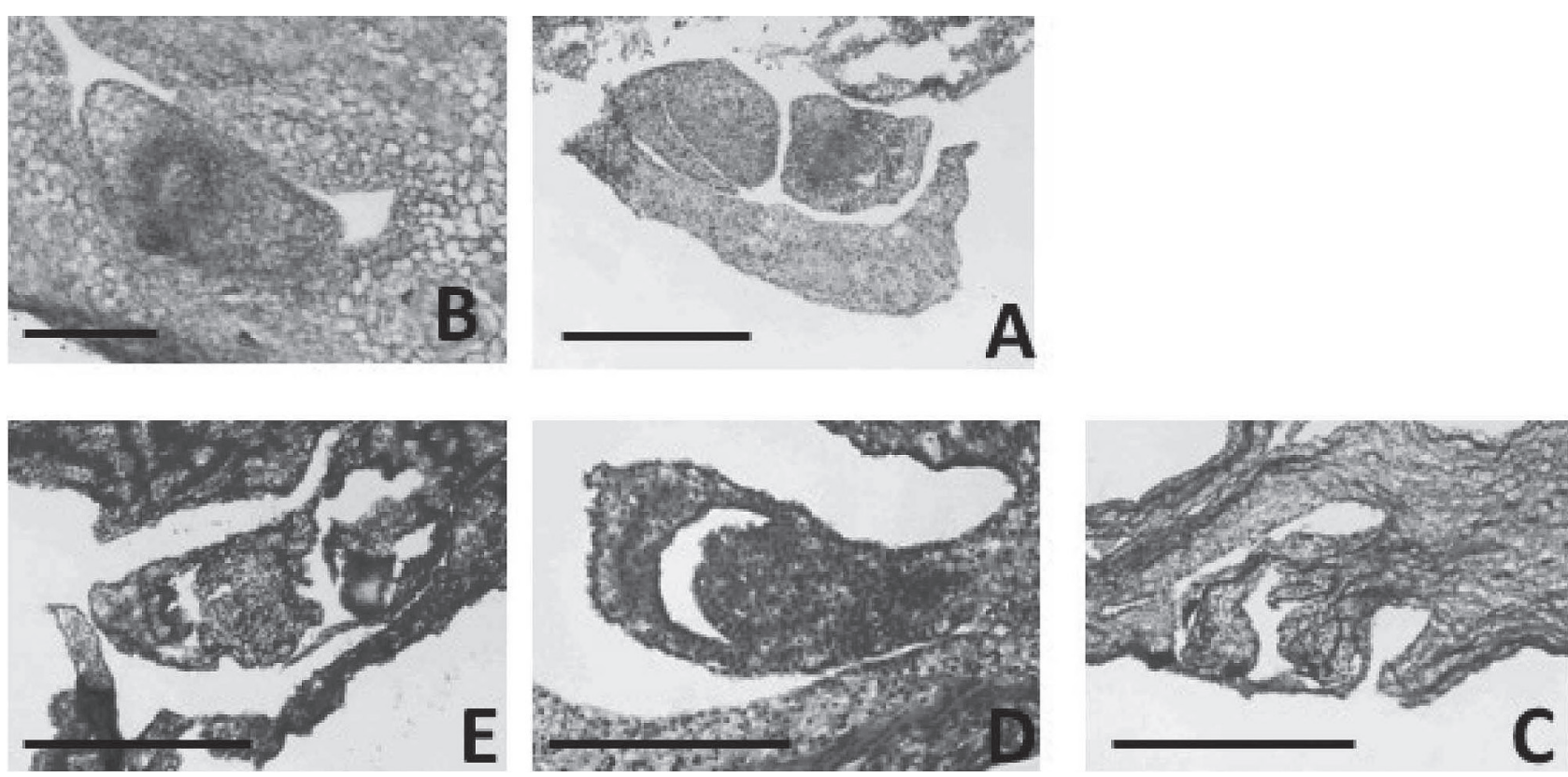

Figure 3. Microscopic evaluation of fresh frozen inflorescences which were processed in different fixatives prior to embedding in optimal cutting temperature (OCT) medium. Untreated inflorescence that was snap frozen directly in liquid nitrogen (A). Inflorescences that were treated with $20 \%$ $(w / v)$ sucrose (B) or fixed in 100\% (v/v) ice-cold butanol (C), or 100\% (v/v) ice-cold ethanol (D) or 100\% (v/v) ice-cold acetone (E), followed by snap freezing in liquid nitrogen. Scale bar $=200 \mu \mathrm{m}$.

in OCT for $20 \mathrm{~min}$. Sucrose has been reported to function as a cryoprotectant by eliminating ice crystal artifacts generated during the freeze-thaw cycle. Hence, it helps to protect the cell membrane and dehydrates the cells by binding to water during freezing (Lineberger and Steponkus, 1980; Rafigue et al., 2015).

As RNA yields from cryosections of inflorescence were too low for evaluation by agarose gel electrophoresis, the RNA was analysed on the Agilent 2100 BioAnalyser. RNA integrity number (RIN) ranging from 1 to 10 was generated for each RNA sample. The higher the RIN score, the higher the RNA quality (Schroeder et al., 2006). In general, RNA extracted from stain-free tissue sections scored higher RIN values compared to those extracted from stained tissue sections. RNA degradation most likely occurred during the staining or ethanol dehydration and rehydration steps. Extra care should be taken during tissue processing. Among the stain-free tissue sections, RNA from tissue sections treated with sucrose or untreated tissues that was vacuuminfiltrated in OCT embedding medium had higher RIN scores (RIN $\geq 6$ ) as well as higher 28S:18S rRNA ratios. Furthermore, RNA yields from untreated and sucrose-treated tissues were higher compared to the other treatments as an equivalent amount of 10 sections at $10 \mu \mathrm{m}$ thickness was processed for each treatment (Table 1). Nevertheless, more tissue sections would be required to ensure enough RNA quantities for downstream gene expression studies.

\section{FFPE and FF Tissue Preparations Offer Unique Advantages}

The FFPE and FF tissue processing procedures of oil palm inflorescences have their own advantages and disadvantages. Tissue processing for the FF tissue was simple and rapid as the entire protocol could be completed within an hour from the fresh tissue sample. Cryopreservation in OCT embedding medium followed by snap freezing in liquid nitrogen minimised the risks of RNA degradation and allowed rapid microscopic inspection of the tissue sections (Shi et al., 2008). Hence, this method would allow the establishment of a biobank for different developmental stages of normal and abnormal inflorescences that can serve as a reliable source for RNA-based analyses. However, the morphology of tissue sections prepared from untreated and directly snap frozen inflorescences showed lower quality of RNA when compared to FFPE sections. The sucrose treatment of fresh oil palm inflorescences used in this study could preserve the morphology and RNA integrity, as well as improve the overall quality of the tissue sections. In comparison with the untreated fresh tissue, this FF tissue preparation approach will help to ease the logistic costs normally incurred in transporting tissues in liquid nitrogen from the sampling site (Micke et al., 2006).

On the other hand, the tediousness and extensive time period needed for FFPE sample preparation may have contributed to RNA fragmentation. 
TABLE 1. BIOANALYSER ELECTROPHEROGRAMS AND GEL ELECTROPHORESIS IMAGES OF THE RNA EXTRACTED FROM FRESH FROZEN (FF) TISSUE SECTIONS. THE FF TISSUES WERE PROCESSED WITH VARIOUS CRYOPRESERVATION PROCEDURES AND WERE EITHER STAINED WITH $1 \%(\mathrm{w} / \mathrm{v})$ TOLUIDINE BLUE OR UNSTAINED

\begin{tabular}{|c|c|c|}
\hline $\begin{array}{l}\text { Cryopreservation } \\
\text { procedure }\end{array}$ & Stain-free tissue sections & Toluidine blue-stained tissue sections \\
\hline $\begin{array}{l}\text { Tissue snap } \\
\text { frozen in liquid } \\
\text { nitrogen }\end{array}$ & 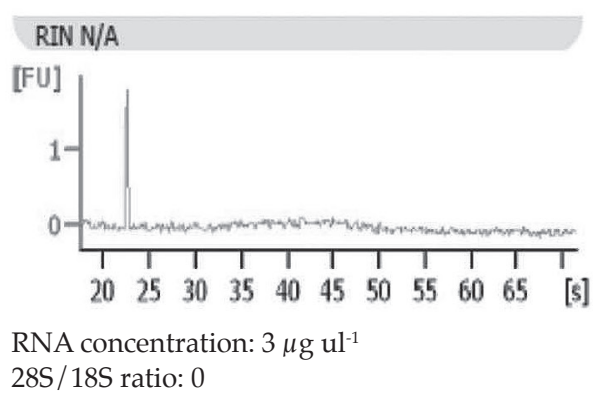 & Unable to obtain intact cryosections \\
\hline $\begin{array}{l}\text { Tissue embedded } \\
\text { in OCT, vacuum- } \\
\text { infiltrated at } 20 \\
\mathrm{mPa} \text { for } 10 \mathrm{~min} \\
\text { and snap frozen } \\
\text { in liquid nitrogen }\end{array}$ & $\begin{array}{l}\text { RIN: } 6.40 \\
\text { [FU] } \\
\text { RNA concentration: } 12 \mu \mathrm{g} \mathrm{ul} \mathrm{l}^{-1} \\
\text { 28S/18S ratio: } 0.4\end{array}$ & $\begin{array}{l}\text { RIN: } 1.40 \\
\text { [FU]_-1 } \\
\text { RNA concentration: } 2 \mu \mathrm{g} \mathrm{ul}^{-1} \\
\text { 28S/18S ratio: } 0\end{array}$ \\
\hline $\begin{array}{l}\text { Tissue embedded } \\
\text { in OCT, vacuum- } \\
\text { infiltrated at } 20 \\
\mathrm{mPa} \text { for } 20 \text { min } \\
\text { and snap frozen } \\
\text { in liquid nitrogen }\end{array}$ & $\begin{array}{l}\text { RIN: } 6.60 \\
\text { [FU] } \\
\text { RNA concentration: } 75 \mu \mathrm{g} \mathrm{ul}^{-1} \\
\text { 28S/18S ratio: } 1.6\end{array}$ & $\begin{array}{l}\text { RIN N/A } \\
\text { [FU] } \\
\text { RNA concentration: } 1 \mu \mathrm{g} \mathrm{ul}^{-1} \\
\text { 28S/18S ratio: } 0\end{array}$ \\
\hline $\begin{array}{l}\text { Tissue treated } \\
\text { with } 20 \% \text { sucrose } \\
\text { and snap frozen } \\
\text { in liquid nitrogen }\end{array}$ & $\begin{array}{l}\text { RIN: } 6.50 \\
\text { RNA] } \\
\text { 28S/18S ratio: } 1.3\end{array}$ & $\begin{array}{l}\text { RIN N/A } \\
\text { [FU]] } \\
\text { RNA concentration: } 8 \mu \mathrm{g} \mathrm{ul}^{-1} \\
\text { 28S/18S ratio: } 0\end{array}$ \\
\hline $\begin{array}{l}\text { Tissue treated } \\
\text { with } 100 \% \\
\text { ethanol and snap } \\
\text { frozen in liquid } \\
\text { nitrogen }\end{array}$ & $\begin{array}{l}\text { RIN: } 2.90 \\
\text { [FU]]-15] } \\
\text { RNA concentration: } 92 \mu \mathrm{g} \mathrm{ul}^{-1} \\
\text { 28S/18S ratio: } 0\end{array}$ & $\begin{array}{l}\text { RIN: } 2.30 \\
\text { [FU] } \\
\text { RNA concentration: } 54 \mu \mathrm{g} \mathrm{ul}^{-1} \\
\text { 28S/18S ratio: } 0\end{array}$ \\
\hline
\end{tabular}

Note: OCT - optimal cutting temperature. 
However, better cell morphology images were obtained with the FFPE inflorescence sections which allowed for better morphological evaluations. Hence, FFPE inflorescence sections may be better suited for localisation studies such as RNA in situ hybridisation that uses short RNA probes (Bowling et al., 2014; Ooi et al., 2012). However, for studies that require higher quality RNA, the fresh frozen tissue preparation method is recommended.

\section{CONCLUSION}

A detailed study was performed to establish a tissue preparation protocol for oil palm inflorescences to obtain tissue sections with high quality RNA and good cellular morphology. Cryosections from FF tissues treated with $20 \%(\mathrm{w} / \mathrm{v})$ sucrose resulted in good RNA yields and quality, with acceptable morphology. In comparison with FFPE tissue sections, the RNA extracted from FF tissue sections was more superior and of higher quality. This established protocol would enable the use of FF cryosections for applications such as laser microdissection, followed by downstream molecular analyses requiring good RNA quality, for example next generation sequencing and transcriptomics studies.

\section{ACKNOWLEDGEMENT}

We are grateful to the Director-General of MPOB for permission to publish this study. This work was supported by research funding from MPOB and the MPOB-Graduate Students Assistantship Scheme (GSAS) programme. We would like to thank Dr Munirah Ahmad from the Institute for Medical Research, Kuala Lumpur, for her valuable insights. We appreciate Zamzuri Ishak for the clonal palms provided for inflorescence sampling. Our gratitude also goes to Azizah Mokri, Roslan Ngadio, Rosna Angsor and Feshah Ishak for their technical support.

\section{REFERENCES}

ADAM, H; JOUANNIC, S; ESCOUTE, J; DUVAL, Y; VERDEIL, J and TREGEAR, J W (2005). Reproductive developmental complexity in the African oil palm (Elaeis guineensis, Arecaceae). Am. J. Bot., 92: 18361852.

BOWLING, A J; PENCE, H E and CHURCH, J B (2014). Application of a novel and automated branched DNA in situ hybridisation method for the rapid and sensitive localization of mRNA molecules in plant tissues. Appl. Plant Sci., 2(4): apps. 1400011. DOI: 10.3732 / apps.1400011.
ELTOUM, I; FREDENBURGH, J; MYERS, R B and GRIZZLE, W E (2001). Introduction to the theory and practise of fixation of tissues. J Histotech., 24: 173-190.

EVERS, D L; HE, J; KIM, Y H; MASON, J T and O'LEARY, T J (2011). Paraffin embedding contributes to RNA aggregation, reduced RNA yield, and low RNA quality. J. Mol. Diagn., 13: 687-694.

GANJALI, H (2012). Tissue processing: an overview. Annals Biol Res., 3: 5374-5378.

GRIZZLE, W E (2009). Models of fixation and tissue processing. Biotech. Histochem., 84: 185-193.

LINEBERGER, R D and STEPONKUS, P L (1980). Cryoprotection by glucose, sucrose and raffinose to chloroplast thylakoids. Plant Physiol., 65: 298-304.

MICKE, P; OHSHIMA, M; TAHMASEBPOOR, S; REN, Z; ÖSTMAN, A; PONTÉN, F and BOTLING, $\mathrm{J}$ (2006). Biobanking of fresh frozen tissue: RNA is stable in nonfixed surgical specimens. Lab Invest., 86: 202-211.

ONG-ABDULLAH, M; ORDWAY, J W; JIANG, N; OOI, S-E; KOK, S-Y; SARPAN, N; AZIMI, N; HASHIM, A T; ISHAK, Z; ROSLI, S K; MALIKE, F A; BAKAR, N A; MARJUNI, M; ABDULLAH, N; YAAKUB, Z; AMIRUDDIN, M D; NOOKIAH, R; SINGH, R; LOW, E T; CHAN, K L; AZIZI, N; SMITH, S W; BACHER, B; BUDIMAN, M A; VAN BRUNT, A; WISCHMEYER, C; BEIL, M; HOGAN, M; LAKEY, $\mathrm{N}$; LIM, C C; ARULANDOO, X; WONG, C K; CHOO, C N; WONG, W C; KWAN, Y Y; ALWEE, S $S$; SAMBANTHAMURTHI, R and MARTIENSSEN, R A (2015). Loss of Karma transposon methylation underlies the mantled somaclonal variant of oil palm. Nature, 525: 533-537.

OOI, S E; LEE, F C and ONG-ABDULLAH, M (2012). $A$ rapid and sensitive in situ RNA hybridisation method for oil palm tissues. J. Oil Palm Res. Vol. 24: 1235-1239.

RAFIGUE, T; YAMAMOTO, $S$; FUKUI, K; MAHMOOD, $Z$ and NIINO, $T$ (2015). Cryopreservation of sugarcane using the $\mathrm{V}$ cryoplate technique. Cryo Letters, 36: 51-59.

RAMACHANDRAN, V; MEILINA, O A; HO, C L; SHARIFAH, S R S A and NAMASIVAYAM, P (2014). Modified RNA in situ hybridization protocol for oil palm (Elaeis guineensis Jacq.) fruit and inflorescence. J. Oil Palm Res. Vol. 26: 300-307.

RAVO, M.; MUTARELLI, M;FERRARO, L; GROBER, O M; PARIS, O; TARALLO, R; VIGILANTE, 
A; CIMINO, D; DE BORTOLI, M; NOLA, E; CICATIELLO, L and WEISZ, A (2008). Quantitative expression profiling of highly degraded RNA from formalin-fixed, paraffin-embedded breast tumor biopsies by oligonucleotide microarrays. Lab Invest., 88: 430-440.

SCHROEDER, A; MUELLER, O; STOCKER, S; SALOWSKY, R; LEIBER, M; GASSMANN, M; LIGHTFOOT, S; MENZEL, W; GRANZOW, $M$ and RAGG, T (2006). The RIN: an RNA integrity number for assigning integrity values to RNA measurements. BMC. Mol. Biol., 7: 3.

SCICCHITANO, MS; DALMAS, D A; BERTIAUZ, M A; ANDERSON, S M; TURNER, L R; THOMAS, R A; MIRABLE, R and BOYCE, R W (2006). Preliminary comparison of quantity, quality and microarray performance of RNA extracted from formalinfixed, paraffin-embedded, and unfixed frozen tissue samples. J. Histochem. Cytochem., 54: 1129-1237.

SHI, S R; LIU, C; POOTRAKUL, L; TANG, L; YOUNG, A; CHEN, R; COTE, R J and TAYLOR, C R (2008). Evaluation of the value of frozen tissue section used as 'gold standard' for immunohistochemistry. Am. J. Clin. Pathol., 129: 358-366.

TEIXEIRA, R T and PEREIRA, H (2011). Laser microdissection applied to plants. Microscopy: Science, Technology, Applications and Education (A Méndez-Vilas and J Díaz eds.). Spain, Formatex Research Center. p. 986-992.

VASSILAKOPOULOU, M; PARISI, F; SIDDIQUI, S; ENGLAND, A; ZARELLA, E R; ANAGNOSTOU, V; KLUGER, Y; HICKS, D G; RIMM, D L and NEUMEISTER, V M (2015). Preanalytical variables and phosphoepitope expression in FFPE tissue: quantitative epitope assessment after variable cold ischemic time. Lab Invest., 95: 334-341.

WALTER, R F; MAIRINGER, F D; WOHLSCHLAEGER, J; WORM, K; TING, S; VOLLBRECHT, C; KURT WERNER, $S$ and HAGER, $\mathrm{T}$ (2013). FFPE tissue as a feasible source for gene expression analysis-a comparison of three reference genes and one tumor marker. Pathol. Res. Pract., 209: 784-789. 